\title{
A study on distribution and population size of Androcymbium hierrense (Colchicaceae) an endangered taxon, in La Palma Biosphere Reserve (Canary Islands)
}

\author{
Félix Manuel Medina ${ }^{1,2 *}$ \& Raúl Fernández de León ${ }^{3}$ \\ ${ }^{1}$ Servicio de Medio Ambiente, Cabildo Insular de La Palma, Avenida Los Indianos n ${ }^{\circ} 20-2^{\circ}$ piso, \\ 38700 Santa Cruz de La Palma, Canary Islands, Spain; felix.medina@cablapalma.es \\ ${ }^{2}$ Island Ecology and Evolution Research Group (IPNA-CSIC), Astrofísico Francisco Sánchez 3, 38206 La Laguna, Tenerife, Canary Islands, Spain \\ ${ }^{3}$ Reserva Mundial de la Biosfera La Palma, Avenida Marítima 3, 38700 Santa Cruz de La Palma, Canary Islands, Spain. ugranfir@gmail.com
}

\begin{abstract}
Medina, F.M. \& Fernández de León, R. 2015. A study on distribution and population size of Androcymbium hierrense (Colchicaceae) an endangered taxon in La Palma Biosphere Reserve (Canary Islands). Anales Jard. Bot. Madrid 72(1): e016

The scarce knowledge on the distribution of the natural populations of the Canarian endemic Androcymbium hierrense (Colchicaceae), an endangered species in the island of La Palma hampers the identification of priorities for undertaking actions for its conservation. Here we present a survey in which, the species is distributed in 14 locations grouped into two differentiated areas. This result represents an increase of ca. $200 \%$ in the occupancy area known for the species until now. A total of 15010 individuals were recorded: 1294 individuals in the northern parts of the island (Garafía), and 13716 in the east (Mazo). The species exhibits an average density of $8.80 \pm 24.03$ SD $(n=1559)$ and an estimated population size of 21593-24851 individuals (with a 95\% confidence interval), given a total population of 217995 plants for the entire species distribution area on the island. Considering these estimates and the current distribution of the species, it is important to analyse its actual conservation status in La Palma both at regional and global scales, taking into account that the main threat for the species is habitat destruction by human activities.
\end{abstract}

Key words: abundance, Androcymbium hierrense, conservation, distribution, endemic species, protected areas

\section{INTRODUCTION}

Biosphere Reserves are recognised areas of representative environments which have been internationally designated within the framework of UNESCO's MAB Program for their value to conservation through providing the scientific knowledge, skills and values to support sustainable development (Bridgewater \& Cresswell, 1998). A relative small area (511 ha) in La Palma Island was declared a Biosphere Reserve in 1983 (El Canal y Los Tiles). Nevertheless, considering both the natural values of this island and that conservation activities were only carried out during a long period after that declaration, the entire island was declared as Biosphere Reserve in 2002 to comply with the other two functions of these natural areas: sustainable development and logistic support for research and educational purposes (UNESCO, 1996). Therefore, La Palma Island Biosphere Reserve harbours a rich biodiversity at regional and national scale. More than 5434 terrestrial species (1056 of them endemic) have

\section{Resumen}

Medina, F.M. \& Fernández de León, R. 2015. Un estudio acerca de la distribución y el tamaño de las poblaciones de Androcymbium hierrense (Colchicaceae) un taxon amenazado, en la Reserva de la Biosfera de La Palma (Islas Canarias). Anales Jard. Bot. Madrid 72(1): e016

El escaso conocimiento que se posee sobre la abundancia y distribución de Androcymbium hierrense (Colchicaceae), una especie vegetal endémica y amenazada del archipiélago canario presente en la isla de La Palma, impide que se puedan establecer las medidas adecuadas para su conservación. En un censo llevado a cabo en 2005, cuyos resultados se presentan en esta contribución, muestran que la especie está distribuida en 14 localidades correspondientes a dos áreas diferentes. Este resultado supone un incremento aproximado del $200 \%$ en su área de ocupación conocida hasta la actualidad. Se contabilizaron un total de 15010 individuos: 1394 plantas en el norte de la isla (Garafía) y 13716 individuos en el este (Mazo). La especie presenta una densidad media de $8.80 \pm 24.03$ SD $(n=1559)$ y un tamaño poblacional estimado de 21593-24851 individuos (con un intervalo de confianza del 95\%), dando una población total de 217995 ejemplares para el total de su área de distribución en la isla. Considerando los resultados obtenidos en este trabajo, sería necesario actualizar su estado de conservación, tanto en la isla de La Palma como a nivel regional y global, teniendo en cuenta que la mayor amenaza para la especie es la destrucción del hábitat como consecuencia de la actividad humana.

Palabras clave: abundancia, Androcymbium hierrense, áreas protegidas, conservación, distribución, especies endémicas

been listed in its territory (Martín \& al., 2005a), and 879 vascular plant species have been described with a $20 \%$ of endemic species. Habitat destruction and, overall, the introduction of invasive species are the most important threats for the conservation of native species on islands worldwide (Mack \& al., 2000, Whittaker \& Fernández-Palacios, 2007), and the Canary Islands are not an exception (GarcíaCasanova \& al., 2001). Of the total of 366 species considered as threatened in the Canarian archipelago (Martín \& al., 2005b), 22 (15 of them plants) are present in La Palma Island (Martín \& al., 2005a).

One of these plant species is Androcymbium bierrense A. Santos, a member of family Colchicaceae. Although it is not included in the Spanish or in the World Conservation Union (IUCN, 2012) endangered species list, it is indeed considered as an endangered taxon by the Spanish Red Data Book (Bañares \& al., 2004, Moreno, 2008), and with the category of threatened in the Canarian endangered species list (Martín \& al., 2005b). This species presents a

\footnotetext{
* Corresponding author.
} 
small distribution area in La Palma Island, being mainly threatened by habitat destruction and, most probably, by grazing by introduced herbivores (Bañares \& al., 2004; Mesa-Coello, 2000).

One of the most important informations for the conservation of any endangered plant species is the location of its populations (Keith, 2000). Thus, in the Canaries, the poor knowledge on the abundance and distribution of natural populations of most endemic endangered plant species clearly stands in the way of their adequate conservation (Carqué-Álamo \& al., 1997). Our main aim in this contribution is to describe the current distribution and population size of Androcymbium hierrense on La Palma Island in order to determine priorities for its conservation.

\section{Natural history of Androcymbium hierrense}

Androcymbium bierrense is an herbaceous plant with a tunicate corm, showing an alternate disposition of leaves (Santos, 1977) (Fig. 1). It is a geophyte with an annual vegetative cycle, which spends the unfavourable period buried as a tunicate corm (Santos, 1977). Plants emerge in November and flower in February; they are hermaphrodite, preferentially xenogamous, facultatively autogamous, and probably entomogamous; vegetative reproduction through corm duplication is frequent, and the distribution of individuals is clumped (Pedrola-Monfort \& Caujapé-Castells, 1998). In La Palma, A. hierrense inhabits basaltic soils, rocky places, or soils with sandy texture in the open communities of xerophytic shrubs (Kleinio-Euphorbietae canariensis, del Arco \& al., 1999) found in the lowest elevations.

The genus Androcymbium represents a disjunct distribution between northern and southern Africa (Caujapé-Castells $\&$ al., 2001). Only two of the ca. 50 species recognized in the genus occur in the Canary Islands: $A$. bierrense in the western islands of La Palma, La Gomera, and El Hierro, and A. psammophilum in the eastern islands of Lanzarote and Fuerteventura (Pedrola-Monfort \& Caujapé-Castells, 1998, Arechavaleta \& al., 2010). Because of slight differences between the population of $A$. bierrense from La Gomera and the other two islands, Reifenberger (1990) proposed the existence of two distinct subspecies, $A$. hierrense subsp. macrospermum (from La Gomera) and A. hierrense subsp. bierrense (from La Palma and El Hierro). Nevertheless, Pedrola-Monfort \& Caujapé-Castells (1995) did not find evidence to support this subdivision taking into account morphological and molecular evidences (Martín Cáceres \& al., 2004).

\section{MATERIAL AND METHODS}

\section{Study area}

The Canarian archipelago is situated in the Atlantic Ocean, and the easternmost island (Fuerteventura) is barely some $100 \mathrm{~km}$ off the African continent. With an area of $728 \mathrm{~km}^{2}$ and a maximum altitude of $2426 \mathrm{~m}$ a.s.l. (Roque de Los Muchachos), the island of La Palma ( $\left.28^{\circ} 40^{\prime} \mathrm{N}, 17^{\circ} 50^{\prime} \mathrm{E}\right)$

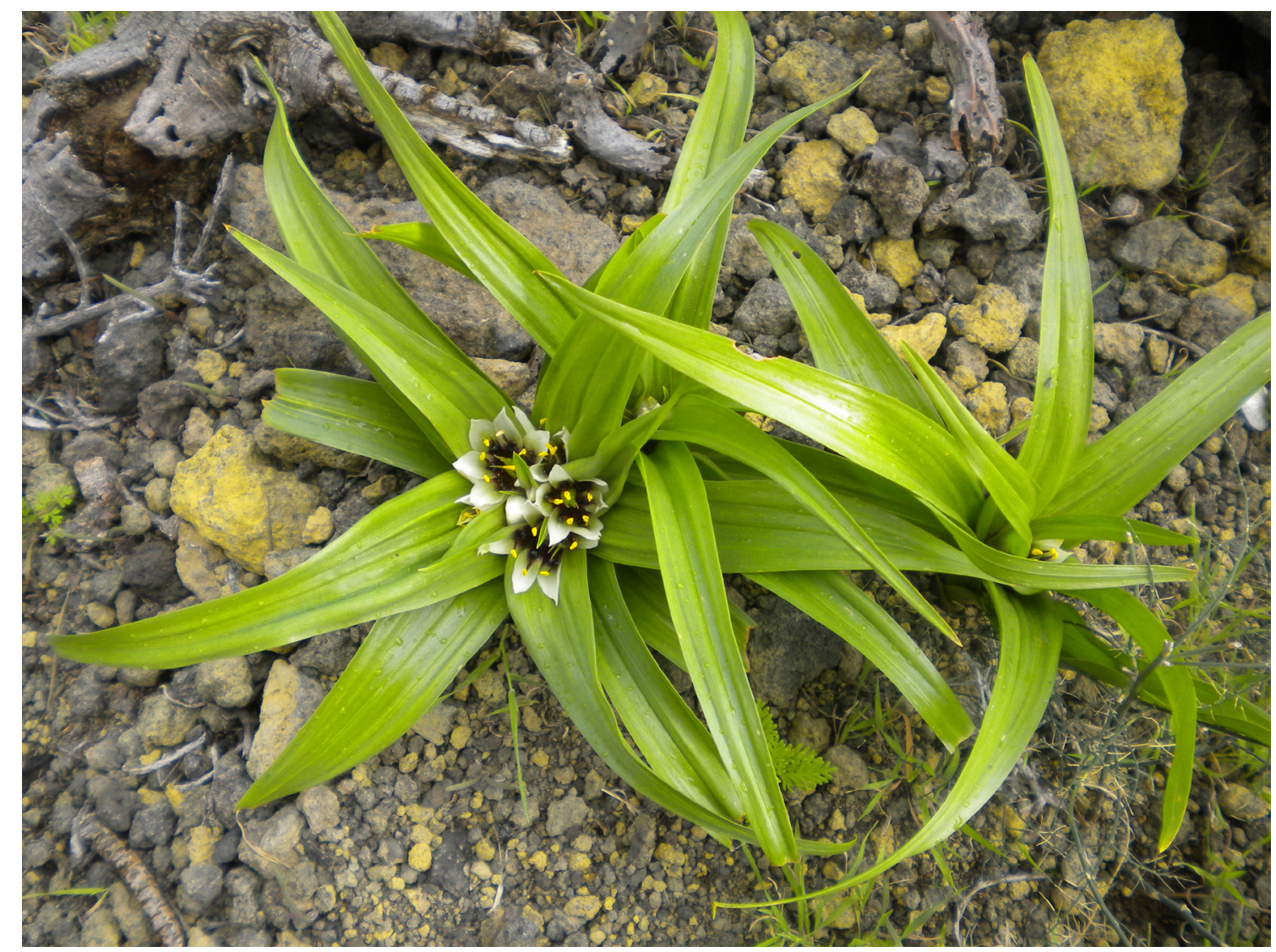

Fig. 1. Detail of Androcymbium hierrense. 


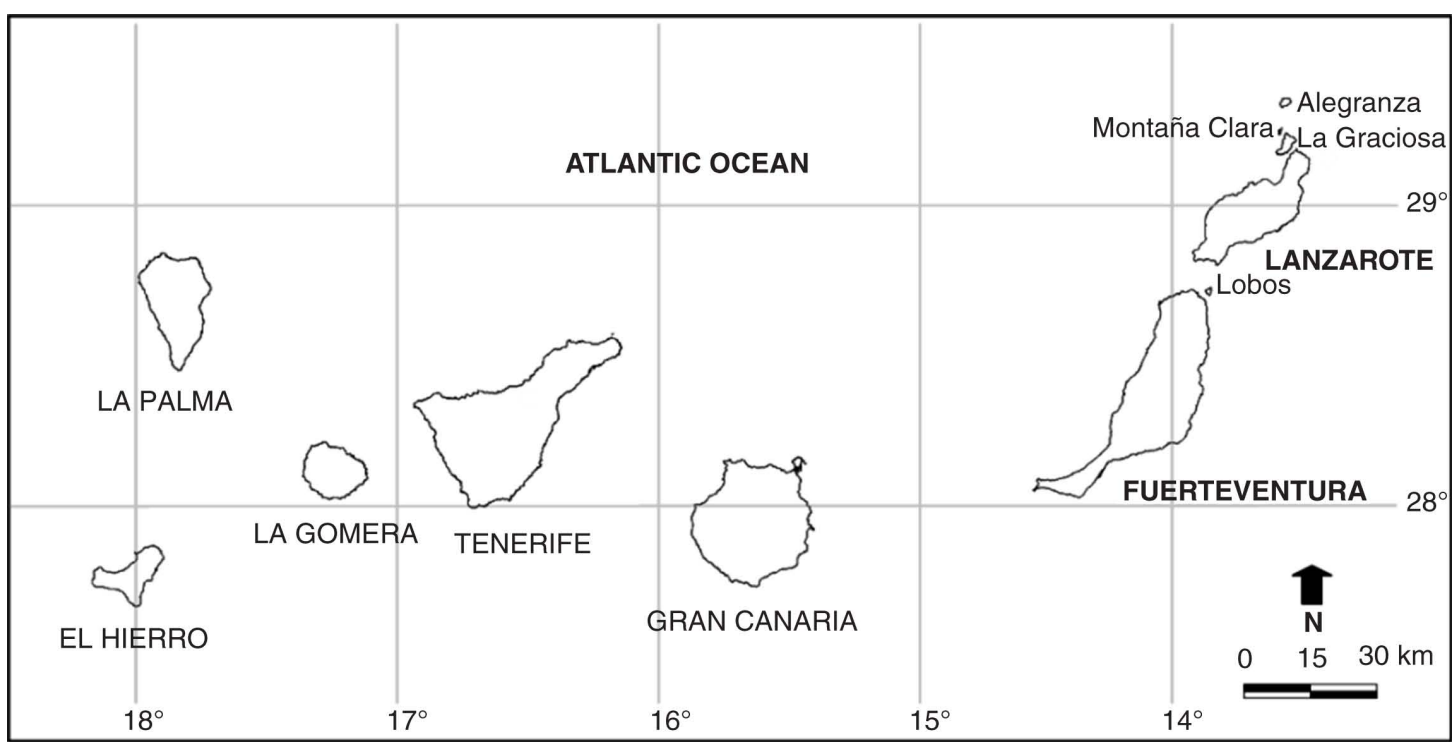

Fig. 2. Map of Canarian Archipelago showing the location of La Palma Island Biosphere Reserve.

is located in the north-west of the archipelago (Fig. 2). This island's climate is influenced by the ecological zones associated with its high altitude, the wet north-east trade winds, and the mountain orientation (Afonso, 1985). The annual rainfall is $400.9 \mathrm{~mm}$ (with seasonal differences [winter $49.9 \%$, autumn $30.7 \%$, spring $18.7 \%$ and summer $0.7 \%$, Marzol-Jaén, 1984]), and the mean annual temperature is $18.3{ }^{\circ} \mathrm{C}$ (Marzol-Jaén, 1984), ranging from $15^{\circ} \mathrm{C}$ in January to $22.3{ }^{\circ} \mathrm{C}$ in August. The different vegetation belts present in the island are related to the altitudinal variation in temperature and precipitation (see Santos, 1983 and del Arco \& al., 1999 for details). We visited an area located in the xerophytic scrubland habitat on the lowest parts of the Island. The vegetation of this area is characterized by the Kleinio-Euphorbietae canariensis association, featuring shrubby vegetation dominated by species such as Euphorbia lamarckii, Retama rhodorbizoides, Lavandula canariensis, Kleinia neriifolia, Echium brevirame, Micromeria herphyllomorpha, Rubia fruticosa and Periploca laevigata (Bañares \& al., 2004).

\section{Methods}

The distribution of Androcymbium hierrense in La Palma Island was estimated on the basis of previous information of its distribution (Mesa-Coello, 2002), and by visiting all the surrounding areas that offer a potential habitat for the species. Each new distribution area was measured and georeferenced in a map using GPS and a GIS program (Arcview 3.2, ESRI, 1992).

Taking into account the clumped distribution of individuals (Pedrola-Monfort \& Caujapé-Castells, 1998), and in order to know the real distribution range of the species, an index of dispersion was calculated following Dale (1999) and Ludwig \& Reynolds (1988). This calculation is based on counts of the number of plants in a set of $n$ quadrats. After the calculation of the average number of plants and sample variance, the index of dispersion formula is:

$$
I_{d}=\sum_{i=1}^{n}\left(x_{i}-\bar{x}\right)^{2} / \bar{x}
$$

where $I_{d}$ is the index of dispersion, and $x_{i}$ is the number of plants in each quadrat (Dale, 1999).

Censuses were carried out in 2005, from March to April, after the plant's flowering period and before its burying as bulb. Two different census strategies were employed depending on the location of the populations. In the eastern parts of the island, characterised by a dense cover of high vegetation (over $95 \%$ and $125 \mathrm{~cm}$, respectively), we followed transects across contiguous quadrats of $2 \times 5 \mathrm{~m}$ (following Keith, 2000; Fig. 3), and the total number of plants present in each quadrat was counted. Four different plant stages were considered: mature, non reproductive, juvenile, and plants affected by herbivores. On the other hand, in the northern parts of the island, all individuals were counted in a specific area, due to the small size of the area of species occurrence. Subsequently, we derived an estimate of the total population cover in relation to the total distribution area. Interval confidence (95\%) was generated using Monte Carlo Analysis from MS-Excel tools. Taking into account that the species can reproduce asexually, clonal plants were not considered in order to avoid bias during the censuses (Bullock, 1996).

\section{RESULTS}

The current distribution of Androcymbium bierrense in La Palma Island is shown in Fig. 4. This species was distributed in 14 locations over two differentiated areas: one in the north, Garafía (three localities at Barranco de Fagundo and one at Punta del Escanchado), and another one in the east Mazo (four localities at Montaña del Azufre, and six in Tigalate) (Fig. 4). Six localities are new: one in the north (Punta del Escanchado) and five in the east (Montaña del Azufre, Lomo 2 Los Morenos, Lomo del Acebuche and Salto Tigalate North), entailing an increase in the species occupancy area of $200 \%$, approximately. 


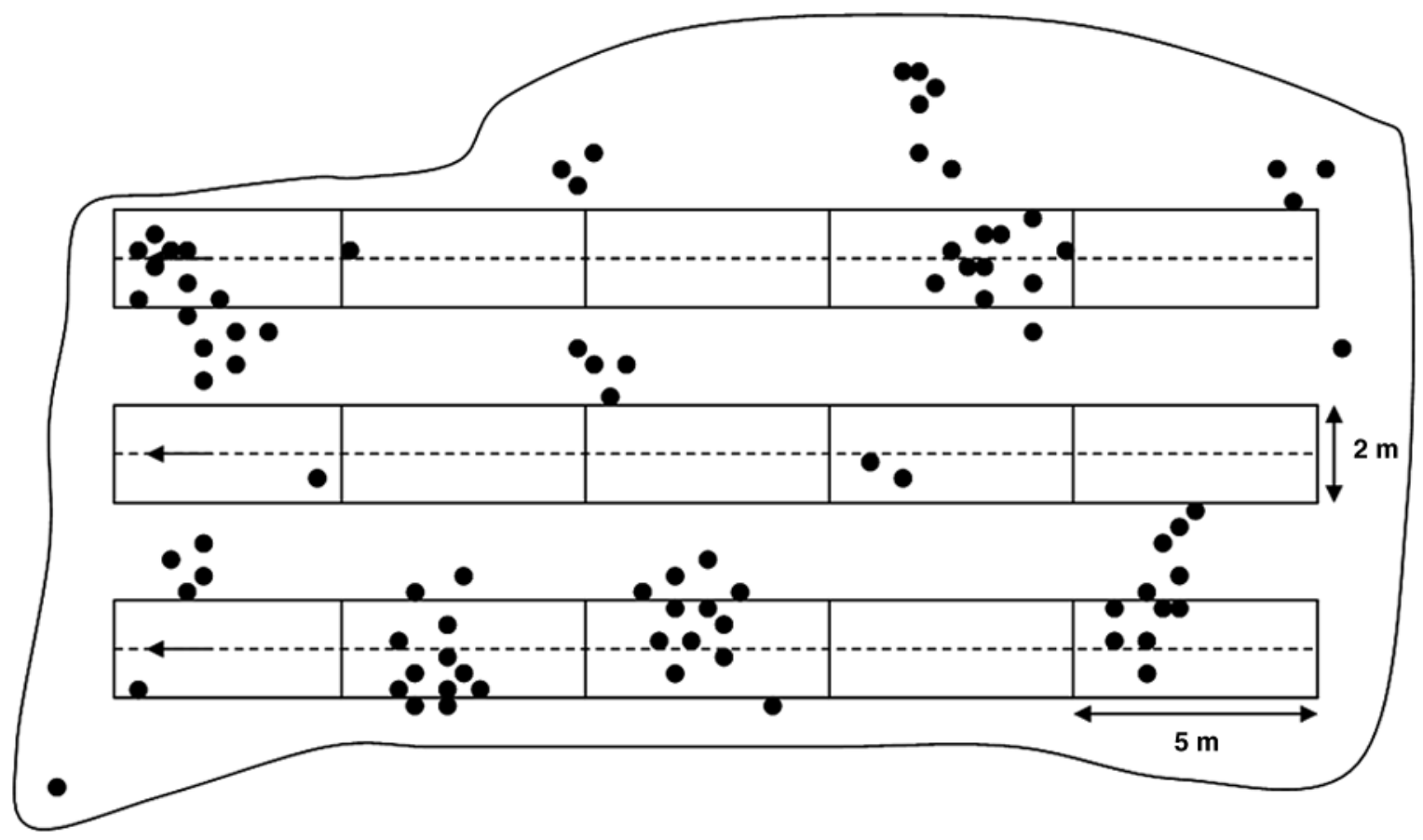

Fig. 3. Census model for Androcymbium hierrense in La Palma Island. Dots: individual plants. Arrows: census direction.
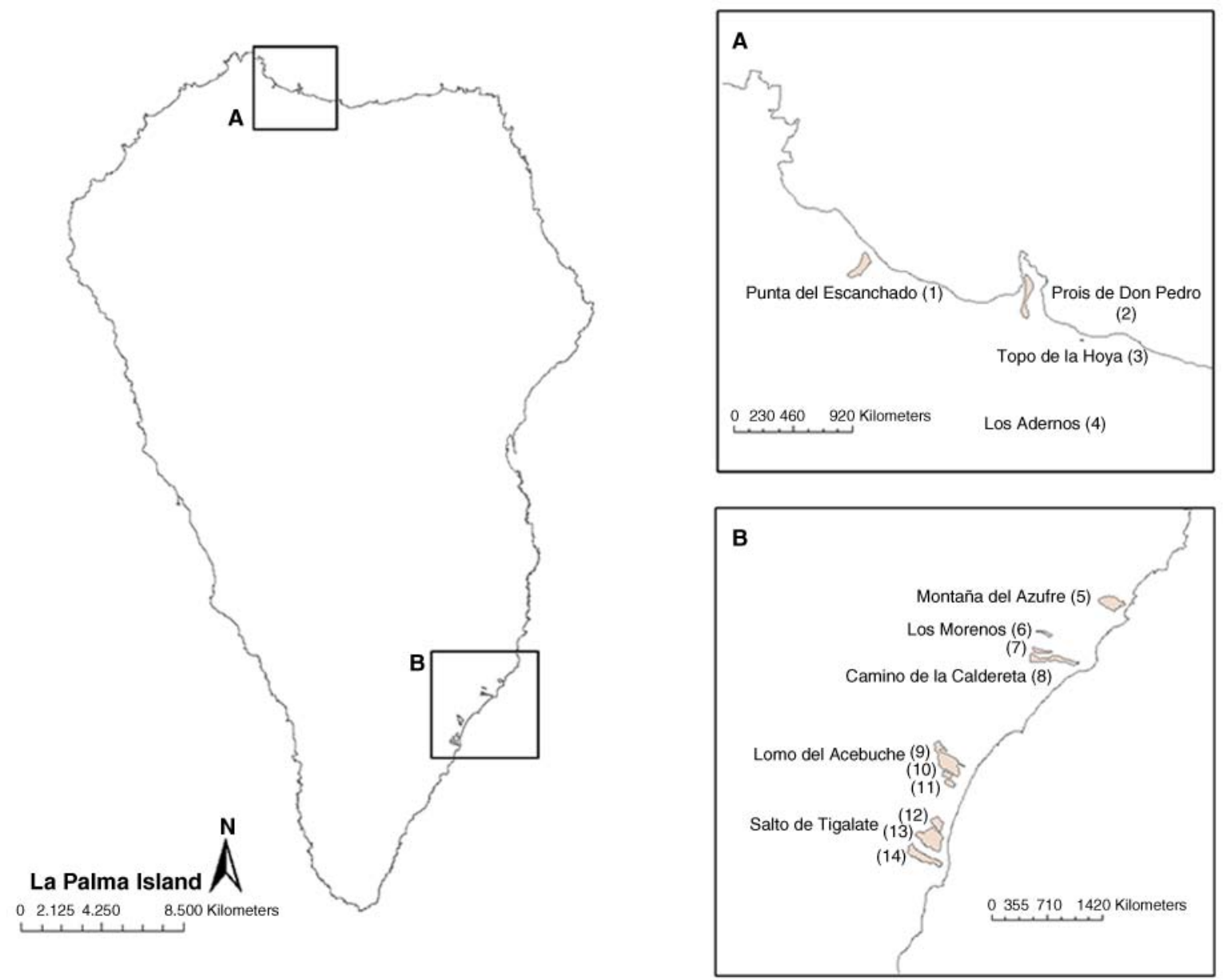

Fig. 4. Map of La Palma showing the distribution of Androcymbium hierrense. A: Garafía, B: Mazo. Numbers correspond to localities in table 1. 
Table 1. Population of Androcymbium hierrense in La Palma Island Biosphere Reserve.

\begin{tabular}{|c|c|c|c|c|c|}
\hline No. map & Locality & Sampled area $\left(\mathrm{m}^{2}\right)$ & No. plants & Total area $\left(\mathrm{m}^{2}\right)$ & Estimated population \\
\hline & GARAFÍA & & & & \\
\hline 1 & Punta del Escanchado & 350 & 17 & 12656.7 & 615 \\
\hline 2 & Prois de Don Pedro & 1718 & 1124 & 13006.5 & 8509 \\
\hline 3 & Topo de la Hoya & 170 & 90 & 170.0 & 90 \\
\hline \multirow[t]{2}{*}{4} & Los Adernos & 25 & 63 & 25.0 & 63 \\
\hline & MAZO & & & & \\
\hline 5 & Montaña del Azufre & 4761 & 964 & 37865.5 & 7667 \\
\hline 6 & Los Morenos & 1300 & 1992 & 5595.2 & 8574 \\
\hline 7 & Lomo 2 Los Morenos & 1690 & 3693 & 8273.3 & 18079 \\
\hline 8 & Camino La Caldereta & 3080 & 1339 & 33252.7 & 14456 \\
\hline 9 & Lomo 1 Acebuche & 850 & 1096 & 65877.4 & 84943 \\
\hline 10 & Lomo 2 Acebuche & 240 & 112 & 7020.0 & 3276 \\
\hline 11 & Lomo 3 Acebuche & 160 & 0 & 160.0 & 0 \\
\hline 12 & Llano 1 Salto Tigalate N & 840 & 364 & 17432.7 & 7554 \\
\hline 13 & Veril Salto Tigalate N & 2810 & 898 & 61540.6 & 19667 \\
\hline \multirow[t]{2}{*}{14} & Salto Tigalate $S$ & 3730 & 3258 & 50949.7 & 44502 \\
\hline & Total & 21564 & 15010 & 313665.3 & 217995 \\
\hline
\end{tabular}

As expected, Androcymbium hierrense presented a clumped distribution with a high index of dispersion $\left(\mathrm{Id}=102219.93 ; \chi_{100}^{2}=149.45 ; \mathrm{p}<0.001\right)$.

A total of 15010 individuals were counted during the census (Table 1). In the north of the island (Garafía), where the species was more narrowly distributed, only 1294 plants were observed (Fig. 5). Although in some places we were able to count all plants, we only surveyed $8.75 \%$ of the total possible area in these localities (ca. $25850 \mathrm{~m}^{2}$ ). This entails an estimated population of 9277 individuals in the northern parts of the island (Table 1). By contrast, in the eastern parts of the island (Mazo), where a census method was used, 13716 individuals were counted, representing the main proportion of the total island population (Table 1, Fig. 5). In this case, species presents a mean density of $8.80 \pm 24.03 \mathrm{SD}$ $(n=1559)$ given a $95 \%$ confidence intervals of 12316-15574 plants.

Finally, these figures give a total population of Androcymbium bierrense for La Palma Biosphere Reserve ranging from 21593 to 24851 plants. Taking into account that the sample area is only $6.9 \%$ of the total occupied area by the

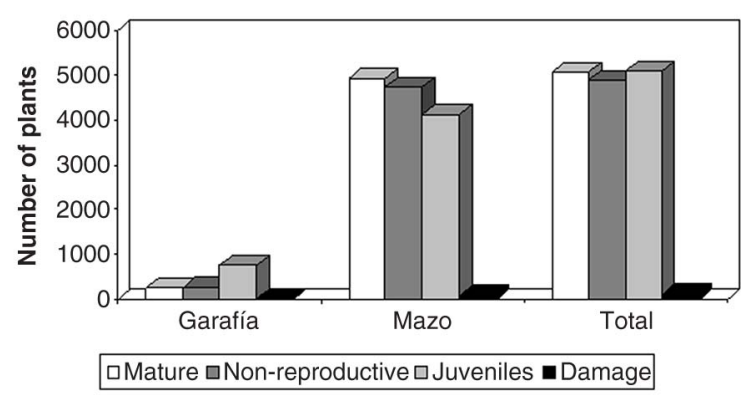

Fig. 5. Number of different plant stages of Androcymbium hierrense counted in La Palma during the survey. species, the total population for the entire distribution area could be conformed by at least 217995 individual plants (Table 1).

\section{DISCUSSION}

Comparing our results with a survey previously carried out (Mesa-Coello, 2002), the distribution of $A$. hierrense species has increased by a high proportion ca 200\%). The cause for such discordance is probably due to the employed methodology used in the previous study, where only a monitoring program of the known populations at that time was performed. The predictive maps obtained in a preliminary study by our group (Medina \& al., 2007), detected new possible locations of distribution of $A$. hierrense on La Palma. Although we used these data to find the new localities reported in this research close to the known distribution range, a more thorough search for all predicted localities was not possible. For this reason, it is likely that new populations could be recorded based on the geographic information system analysis. Actually, in March 2011, a new population of this species composed by few hundreds of plants was discovered in Montaña de La Laguna, in the western parts of the island (Laura Concepción, pers. com.). Species distribution modelling constitutes an important predictive tool for ecology and conservation biology (Guisan \& Thuiller, 2005). This is the first time that such a great effort has been undertaken to assess the current status of this endangered species following the potential distribution predicted by GIS procedures (Medina \& al., 2007).

The distribution of annual plant species on a local scale can be limited by their dispersal limitation (Primack \& Maio, 1992). As commented, Androcymbium bierrense has a low dispersal capacity, so it tends to occur almost exclusively in suitable habitat patches (Pulliam, 2000) as occurred in our case where we should counted more than the $99.6 \%$ of the total previously knowing population. 


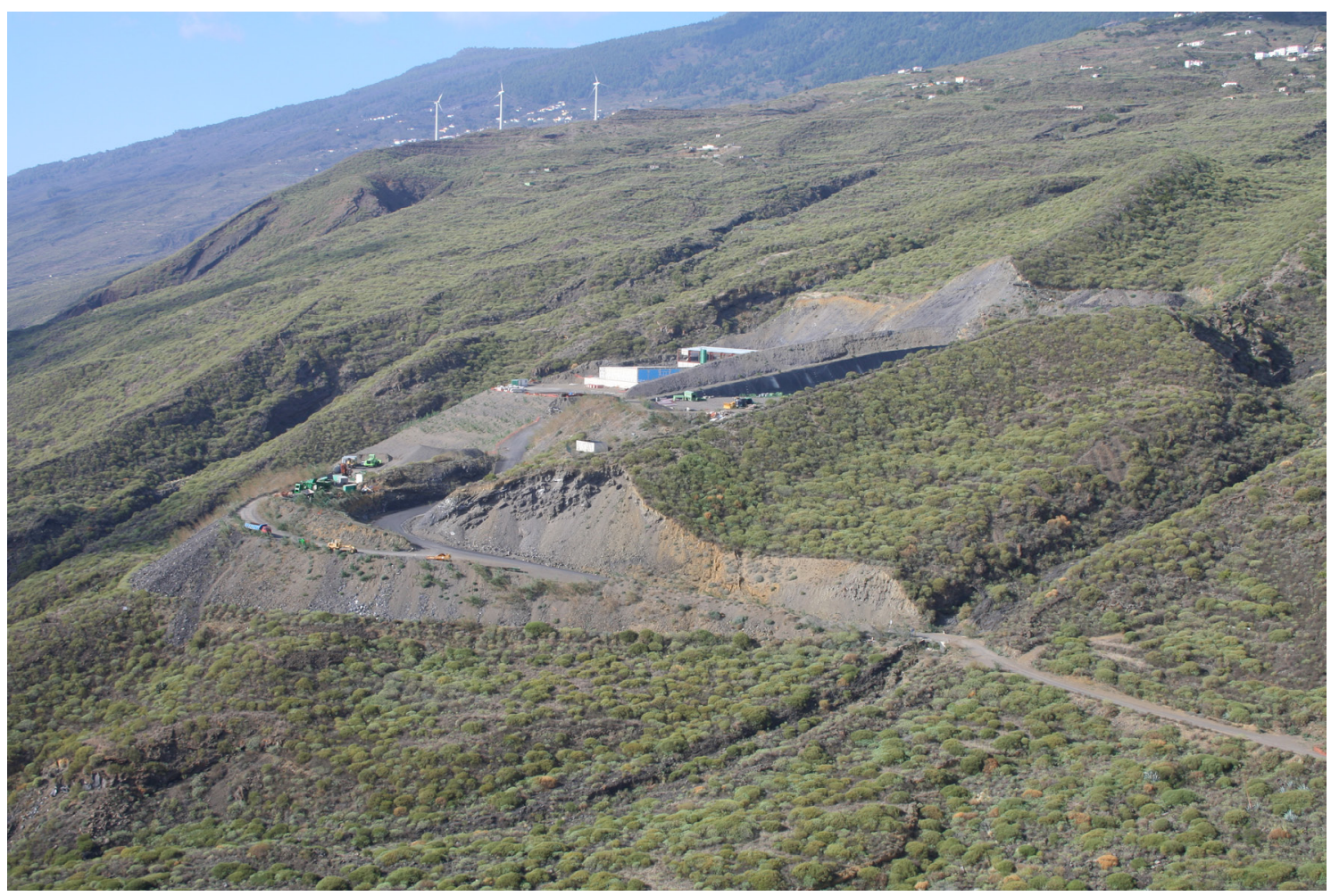

Fig. 6. Human activities act as the principal threat for the conservation of Androcymbium hierrense on La Palma Island Biosphere Reserve. The image shows the rubbish dump whose construction entailed the destruction of one of the locations of $A$. hierrense (Los Morenos).

Although population structuring was not the main objective of this study, the observed unbalance between the different age classes (Fig. 5) seems to indicate that the population is fragile due to the existence of some factor that limits recruitment as it has been highlighted in other endangered species in the Canary Islands (Marrero-Gómez \& al., 1999). From these results, though herbivory is not the main threat for the species but habitat destruction it is important to take this into account in order to avoid undeliverable effects on this plant species.

\section{Conservation priorities}

Taking into account the population size and the current distribution of the species, we consider it of utmost interest to reassess the present status of this species in $\mathrm{La}$ Palma Island at global and regional scales following the criteria of the World Conservation Union (IUCN, 2001) and the Canary Island Government (Martín \& al., 2005b). On the other hand, considering the strong pressure created by introduced herbivores such as rabbits, rats or livestock (cows and goats), we support Bañares \& al. (2004) view who established habitat destruction by human activities as the main threat for the species. In this respect, one of the largest localities for $A$. bierrense on La Palma (Los Morenos, see Table 1 and Fig. 4) was recently destroyed by the construction of a rubbish dump (Fig. 6). This work emphasizes the utility of species distribution modelling for conservation purposes. The performed model distribution (Medina \& al., 2007) has allowed us both to select a nearby area where relocate part of the affected population, and to discover new populations of this endangered species in the Biosphere Reserve.

\section{ACKNOWLEDGEMENTS}

We thank the staff of Servicio de Medio Ambiente del Cabildo Insular de La Palma for their support, particularly to Guillermo Hernández, Isidro Martín, J. David Martín, Diego M. Álvarez, Epifanio Hernández, and Elena Castro, who helped us during field work and censuses. Alicia Martín Gobea also helped us during the field work. Aurelio Acevedo, Antonio R. Lerín, Katia Martín Cáceres, Arnoldo Santos and Laura Concepción showed us new areas of species distribution. Juan Antonio Bermejo and Rafael García Martín collaborated in the elaboration of maps. Juli Caujapé-Castells and Eduardo Carqué-Álamo revised an early stage of this manuscript.

\section{REFERENCES}

Afonso, L. 1985. La Palma. In: Afonso, L. (ed.), Geografía de Canarias IV: 10-94. Editorial Interinsular Canaria, Santa Cruz de Tenerife.

Arechavaleta, M., Rodríguez, S., Zurita, N. \& García, A. (Coord.). 2010. Lista de especies silvestres de Canarias (bongos, plantas y animales terrestres) 2009. Consejería de Política Territorial y Medio Ambiente, Gobierno de Canarias, Santa Cruz de Tenerife. 579 pp.

Bañares, A., Blanca, G., Güemes, J., Moreno, J.C. \& Ortiz, S. (Eds.). 2004 Atlas y libro rojo de la flora vascular amenazada de España. Dirección General para la Biodiversidad, Publicaciones del O.A.P.N. Madrid. 1069 pp.

Bridgewater, P.B. \& Cresswell, I.D. 1998. The reality of the world network of Biosphere Reserves: its relevance for the implementation of the Convention on Biological Diversity. In: Proceedings of a Workshop at the 1996 IUCN World Conservation Congress, Montreal, Canada, Biosphere Reserves-myth or reality?: 1-6. IUCN, Gland, Switzerland and Cambridge, UK.

Bullock, J. 1996. Plants. In: Sutherland, W.J. (ed.), Ecological census techniques: a handbook: 111-138. Cambridge University Press, Cambridge.

Carqué-Álamo, E., Marrero-Gómez, M., Bañares-Baudet, A., PalomaresMartínez, A. \& Fernández-López, A. 1997. Corología y estructura de las poblaciones de algunos endemismos vegetales canario-madeirensis en peligro de extinción. Vieraea 26: 23-45.

Caujapé-Castells, J., Jansen, R.K., Membrives, N., Pedrola-Monfort, J., Montserrat, J.M. \& Ardanuy, A. 2001. Historical biogeography of 
Androcymbium Willd. (Colchicaceae) in Africa: evidence from cpDNA RFLPs. Botanical Journal of the Linnean Society 136: 379-392. http:// dx.doi.org/10.1111/j.1095-8339.2001.tb00581.x

Dale, M.R.T. 1999. Spatial pattern analysis in plant ecology. Cambridge University Press, Cambridge. 326 pp. http://dx.doi.org/10.1017/ CBO9780511612589

del Arco, M., Acebes, J.R., Pérez de Paz, P.L., Marrero, M.C. 1999. Bioclimatology and climatophilus vegetation of Hierro (part 2) and La Palma (Canary Islands). Phytocoenologia 29: 253-290. http://dx.doi. org/10.1127/phyto/29/1999/253

ESRI (Environmental Systems Research Institute). 1992. ArcView GIS: Release 3.2 [software]. Redlands, California.

García-Casanova, J., Rodríguez-Luengo, J.L. \& Rodríguez-Piñero, C. 2001. Especies amenazadas. In: Fernández-Palacios, J.M. \& Martín-Esquivel, J.L. (eds.), Naturaleza de las Islas Canarias: ecología y conservación: 167-172. Publicaciones Turquesa S. L., Santa Cruz de Tenerife.

Guisan, A. \& Thuiller, W. 2005. Predicting species distribution: offering more than simple habitat model. Ecology Letters 8: 993-1009. http:// dx.doi.org/10.1111/j.1461-0248.2005.00792.x

IUCN. 2001. IUCN Red List Categories and Criteria: Version 3.1. IUCN Species Survival Comission. IUCN, Gland, Switzerland and Cambridge, UK. ii +30 pp.

IUCN. 2012. IUCN Red List of Threatened Species. Version 2012.2. <www. iucnredlist.org > . Downloaded on 12 April 2013.

Keith, D.A. 2000. Sampling designs, field techniques and analytical methods for systematic plant population surveys. Ecological Management E Restoration 1: 125-139. http://dx.doi.org/10.1046/j.1442-8903.2000. 00034.x

Ludwig, J.A. \& Reynolds, J.F. 1988. Statistical ecology: a primer on methods and computing. Willey \& Sons, New York. 337 pp.

Mack, R.N., Simberloff, D., Lonsdale, W.M., Evans, H., Clout, M. \& Bazzaz, F.A. 2000. Biological invasions: causes, epidemiology and global consequences, and control. Ecological Applications 10: 689-710. http://dx.doi. org/10.1890/1051-0761(2000)010[0689:BICEGC]2.0.CO;2

Marrero-Gómez, M., Bañares-Baudet, A., Carqué-Álamo, E. \& Padilla-Cubas, A. 1999. Size structure in populations of two threatened endemic plant species of the Canary Islands: Cistus osbaeckiaefolius and Helianthemum juliae. Natural Areas Journal 19: 79-86.

Martín, J.L., Marrero, M., Zurita, N., Arechavaleta, M. \& Izquierdo, I. 2005a. Biodiversidad en gráficas. Especies silvestres de las Islas Canarias. Consejería de Medio Ambiente y Ordenación Territorial, Gobierno de Canarias. 56 pp.

Martín, J.L., Fajardo, S., Cabrera, M.A., Arechavaleta, M., Aguiar, A., Martín, S. \& Naranjo, M. 2005b. Evaluación 2004 de especies amenazadas de Canarias. Especies en peligro de extinción, sensibles a la alteración de su bábitat y vulnerables. Consejería de Medio Ambiente y Ordenación Territorial, Gobierno de Canarias. 95 pp.

Martín Cáceres, K., Mesa Coello, R. \& Santos Guerra, A. 2004. Androcymbium bierrense Santos subsp. hierrense. In: Bañares, A., Blanca, G., Güemes, J., Moreno, J.C. \& Ortiz, S. (eds.), Atlas y libro rojo de la flora vascular amenazada de España: 576-577. Dirección General para la Biodiversidad, Publicaciones del O.A.P.N. Madrid.

Marzol-Jaén, M.V. 1984. El Clima de Canarias. In: Afonso, L. (ed.), Geografía de Canarias I: 157-202. Editorial Interinsular Canaria, Santa Cruz de Tenerife.

Medina, F.M., Fernández de León, R. \& Bermejo, J.A. 2007. Predictive modelling for conservation prioritization of Androcymbium bierrense, an endangered species on a Biosphere Reserve (La Palma, Canary Islands). 3rd Biennial Conference of The International Biogeography Society. Puerto de La Cruz, Tenerife, 3-9 January 2007.

Mesa-Coello, R. 2002. Seguimiento de poblaciones de especies amenazadas 2002: Androcymbium hierrense A. Santos ssp. hierrense La Palma. Consejería de Política Territorial y Medio Ambiente del Gobierno de Canarias. Unpublished report.

Moreno, J.C., coord. 2008. Lista Roja 2008 de la flora vascular española. Dirección General de Medio Natural y Política Forestal (Ministerio de Medio Ambiente, y Medio Rural y Marino) y Sociedad Española de Biología de Conservación de Plantas, Madrid. 86 pp.

Pedrola-Monfort, J. \& Caujapé-Castells, J. 1995. Genetic structure of a narrow endemic plant: Androcymbium europaeum (Lange) K. Richter (Colchicadeae). Botánica Macaronesica 21: 85-94.

Pedrola-Monfort, J. \& Caujapé-Castells, J. 1998. The Androcymbium species of the Canary Islands. Curtis's Botanical Magazine 15: 67-77. http:// dx.doi.org/10.1111/1467-8748.00134

Pullian, H.R. 2000. On the relationship between niche and distribution. Ecology Letters 3: 349-361. http://dx.doi.org/10.1046/j.1461-0248. 2000.00143.x

Reifenberger, U. 1990. Androcymbium hierrense Santos ssp. macrospermum Reifenberger ssp. nov. (Liliaceae), ein neuer Endemit der Insel La Gomera. Vieraea 18: 251-259.

Santos, A. 1977. Androcymbium hierrensis spec. nova para la flora canaria. II Congresso Internacional pro Flora (Funchal): 53-59.

Santos, A. 1983. Flora y vegetación de La Palma. Editorial Interinsular Canaria, Santa Cruz de Tenerife. 348 pp.

UNESCO. 1996. Reservas de biosfera: la estrategia de Sevilla y el marco estatutario de la Red Mundial. UNESCO, Paris. 20 pp.

Associate Editor: Javier Fuertes Received: 28-X-2014 Accepted: 19-V-2014 